\title{
Incidence of bifurcation coronary lesion as a culprit lesion in patients with acute myocardial infarction: impact of treatment strategy on short and long term outcomes
}

\author{
Akut miyokart enfarktüsü olan hastalarda sorumlu lezyonun bifurkasyon lezyon olma \\ sıklığı: seçilen tedavi stratejisinin erken ve geç dönem sonuçlara etkisi \\ Hazar Harbalıoğlu, Caner Türkoğlu, Taner Şeker, Alaa Quisi, Ömer Genç, Gökhan Alıcı, Samir \\ Allahverdiyev, Ahmet Oytun Baykan, Mustafa Gür
}

Gönderilme tarihi:20.03.2020

Kabul tarihi:20.04.2020

\begin{abstract}
Purpose: Although, there are several studies comparing single and two-stent techniques in patients with bifurcation lesions, evidence in patients presenting with myocardial infarction (MI) is still insufficient. We aimed to assess the short and long term outcomes of provisional and two-stent techniques of bifurcation lesions in patients with ACS.

Materials and methods: 2992 patients with MI who underwent percutaneous coronary intervention $(\mathrm{PCl})$ were enrolled in the present study. Of 2992 patients, 385 patients with MI had bifurcation lesions. The Synergy between $\mathrm{PCl}$ with TAXUS ${ }^{\mathrm{TM}}$ and Cardiac Surgery (SYNTAX) score, pre-PCl Thrombolysis in Myocardial Infarction (TIMI) flow, post-PCI TIMI flow, duration of procedure, angiographic features, post-PCI side branch loss, 1- and 12-month mortality rates were noted.

Results: 169 (43.9\%) patients had ST segment elevation MI, whereas $216(56.1 \%)$ patients had non-ST segment elevation MI. $355(92.2 \%)$ patients underwent provisional stenting and $30(7.8 \%)$ patients underwent two-stent technique. Side branch loss was observed in 40 patients $(11.2 \%)$ in the provisional group and 1 patient $(3.3 \%)$ in the two-stent group $(p=0.2)$. Compared to provisional group, durations of angiography and revascularization in two-stent group were significantly longer $(p<0.001$ and $p<0.001)$. Both 1 -month and 12-month mortality rates were similar in provisional and two-stent groups $(4.2 \%$ vs. $3.3 \%, p=0.8$ and $11.5 \%$ and $13.3 \%, p=0.7$; respectively).

Conclusion: In patients presenting with ACS and bifurcation lesions, procedural success, side branch loss, as well as short and long term mortality were similar in both provisional and two-stent techniques.
\end{abstract}

Key words: Acute coronary syndrome, bifurcation, revascularization, side branch loss, mortality.

Harbalioglu H, Turkoglu C, Seker T, Quisi A, Genc O, Alici G, Allahverdiyev S, Baykan AO, Gur M. Incidence of bifurcation coronary lesion as a culprit lesion in patients with acute myocardial infarction: impact of treatment strategy on short and long term outcomes. Pam Med J 2020;13:519-527.

Özet

Amaç: Bifurkasyon lezyonu olan hastalarda provizyonel teknik ile çift stent tekniğini karşılaştıran çalışmalar mevcuttur. Ancak, miyokart enfarktüsü (ME) tanısı alan ve bifurkasyon lezyonu saptanan hastalarda revaskülarizasyon tekniği ile ilgili çalışmalar yeterli değildir. Çalışmamızda ME tanısı alan ve bifurkasyon lezyonu saptanan hastalarda provizyonel yöntem ve çift stent tekniğinin erken ve geç dönem sonuçları üzerine olan etkisini araştırmayı amaçladık.

Hazar Harbalıoğlu, MD. Department of Cardiology, Duzce Ataturk State Hospital, Duzce, Turkey, e-mail: hazarhmail@hotmail.com (orcid. org/0000-0002-6694-814X) (Corresponding Author)

Caner Türkoğlu, MD. Department of Cardiology, Malatya Numune Training and Research Hospital, Malatya, Turkey, e-mail: canerturkoglu83@ hotmail.com (orcid.org/0000-0003-1275-630X)

Taner Şeker, MD. Department of Cardiology, University of Health Sciences Adana Numune Training and Research Hospital, Adana, Turkey, e-mail: atanerseker@hotmail.com (orcid.org/0000-0003-4254-907X)

Alaa Quisi, MD. Department of Cardiology, Medline Adana Hospital, Adana, Turkey, e-mail: dr.quisi@hotmail.com (orcid.org/0000-0002-58625789)

Ömer Genç, MD. Department of Cardiology, Agri State Hospital, Agri, Turkey, e-mail: dr.genc@hotmail.com (orcid.org/0000-0002-9097-5391) Gökhan Alıcı, MD. Department of Cardiology, Okmeydanı Training and Research Hospital, Istanbul, Turkey, e-mail: gokhan alici1@hotmail. com (orcid.org/0000-0002-4589-7566)

Samir Allahverdiyev, MD. Department of Cardiology, I.A.Ü. VM Medical Park Florya, Istanbul, Turkey, e-mail: dr.samir.av@gmail.com (orcid. org/0000-0003-3175-0835)

Ahmet Oytun Baykan, MD. Department of Cardiology, Ortadoğu Adana Hospital, Adana, Turkey, e-mail: oytunbaykan@yahoo.com (orcid. org/0000-0002-6103-2511)

Mustafa Gür, MD. Department of Cardiology, University of Health Sciences Adana Numune Training and Research Hospital, Adana, Turkey, e-mail: drmugur@yahoo.com (orcid.org/0000-0002-3841-5282) 
Gereç ve yöntem: Miyokart enfarktüsü tanısı alan 2992 hastadan bifurkasyon lezyonu olan 385 hasta çalışmaya dahil edildi. Hastaların Synergy between PCI with TAXUS ${ }^{\mathrm{TM}}$ and Cardiac Surgery (SYNTAX) skoru, işlem öncesi Thrombolysis in Myocardial Infarction (TIMI) skoru, işlem süresi, anjiyografik özellikleri, işlem sonrası TIMI skoru, işlem sonrası yan dal kaybı, 30 günlük ve 1 yıllık mortalite bilgileri değerlendirildi.

Bulgular: $169(\% 43,9)$ hasta ST segment yükselmeli miyokart enfarktüsü (STYME), $216(\% 56,1)$ hasta ST segment yükselmesi olmayan miyokart enfarktüsü (NSTYME) olarak değerlendirildi. $355(\% 92,2)$ hastaya provizyonel teknik, $30(\% 7,8)$ hastaya çift stent tekniği uygulandı. Provizyonel stentleme uygulanan hastaların 40 'ında $(\% 11,2)$ yan dal kaybı gelişti. Çift stent tekniği uygulanan hastaların 1 'inde $(\% 3,3)$ yan dal kaybı meydana geldi $(p=0,2)$. Çift stent tekniği uygulanan hastalarda anjiyografi süresi ve işlem süresi anlamlı olarak daha uzundu $(p<0,01, p<0,001)$. 30 günlük mortalite provizyonel grupta $\% 4,2$ iken, çift stent grubunda $\% 3,3$ olarak saptandı $(p=0,8)$. 1 yıllık mortalite provizyonel grupta $\% 11,5$ iken çift stent grubunda $\% 13,3$ olarak görüldü $(p=0,7)$.

Sonuç: Miyokart enfarktüsü ile başvuran ve bifurkasyon lezyonu saptanan hastalarda; revaskülarizasyon yöntemi olarak çift stent tekniği ile provizyonel yöntem karşılaştırıldığında yan dal kaybı, erken dönem ve geç dönem mortalite oranlarında anlamlı bir farklıık bulunmamıştır.

Anahtar kelimeler: Akut koroner sendrom, bifurkasyon, revaskülarizasyon, yan dal kaybı, mortalite.

Harbalıoğlu H, Türkoğlu C, Şeker T, Quisi A, Genç O, Alıcı G, Allahverdiyev S, Baykan AO, Gür M. Akut miyokart enfarktüsü olan hastalarda sorumlu lezyonun bifurkasyon lezyon olma sıklığı ve seçilen tedavi stratejisinin erken ve geç dönem sonuçlara etkisi. Pam Tıp Derg 2020;13:519-527.

\section{Introduction}

Acute coronary syndromes (ACS), result from the corruption of plaque integrity that restricts blood flow in the coronary arteries, may be presented as ST-segment elevation myocardial infarction (STEMI), non-ST segment elevation myocardial infarction (non-STEMI) or unstable angina pectoris (USAP) [1-3].

$15-20 \%$ of coronary lesions are bifurcation lesions. It is well known that atherosclerosis is frequently seen due to increased turbulence and high wall stress in bifurcation areas [4]. Percutaneous coronary intervention ( $\mathrm{PCl}$ ) for bifurcation lesions is more complex than intervention of non-bifurcated lesions, which results in lower success rates, longer procedure duration, and higher likelihood of restenosis. Provisional stenting is a less complicated procedure due to fewer major cardiac events, less radiation exposure, shorter treatment time, and less use of contrast material [5].

In the present study, our aim to investigate the early and late results of the two-stent technique and the provisional method in bifurcation lesions in patients presenting with MI.

\section{Methods}

\section{Study population}

This study was obtained from Adana Numune Training and Research Hospital, Adana, respectively. During the period from
January to December 2014, 2992 consecutive patients presenting with $\mathrm{MI}(73.5 \%$ men; mean age $59.7 \pm 12.7$ years) who underwent $\mathrm{PCl}$ for infarct related artery (IRA) were included in this retrospective study. A total of 385 patients who had bifurcation lesions (283 male, 102 female) were included. 355 patients were treated with provisional technique (single stent) and 30 patients were treated with two-stent technique. Patients who had a side branch diameter $<2 \mathrm{~mm}$, patients who had a history of coronary artery bypass graft operation, patients diagnosed with stable angina pectoris or USAP were excluded from the study. The study was conducted according to the recommendations set forth by the Declaration of Helsinki on Biomedical Research Involving Human Subjects. The Institutional Ethics Committee approved the study protocol and each participant provided written informed consent.

After taking detailed medical history and complete physical examination, each participant was questioned for major cardiovascular risk factors such as age, sex, diabetes mellitus (DM), smoking status and hypertension (HT). Acute myocardial infarction was defined according to the third universal definition of myocardial infarction [6]. Accordingly, MI was defined as evidence of cardiac necrosis characterized by a rise and/or fall of cardiac biomarkers, especially cardiac troponin (with at least one value above the 99th percentile upper reference limit) in a clinical setting consistent with acute myocardial ischemia. STEMI 
was defined as $\mathrm{Ml}$ with the presence of new prolonged (> $20 \mathrm{~min}$ ) ST-segment elevation at the $\mathrm{J}$ point in two contiguous leads with ageand sex-dependent cut-points (leads V2-V3: $\geq 0.25 \mathrm{mV}$ in men $<40$ years, $\geq 0.2 \mathrm{mV}$ in men $\geq 40$ years, and $\geq 0.15 \mathrm{mV}$ in women; all other leads: $\geq 0.1 \mathrm{mV}$ ), true posterior MI (ST-segment elevation in leads $\mathrm{V} 7-\mathrm{V} 9 \geq 0.1 \mathrm{mV}$ in men $<40$ years and $\geq 0.05 \mathrm{mV}$ in men $\geq 40$ years and women, usually combined with ST depression in V1-3) or new left bundle branch block. All $\mathrm{MI}$ is not meeting the criteria for STEMI were classified as non-STEMI.

\section{Angiographic analysis}

Standard selective coronary angiography was performed using the Judkins technique. Coronary lesions leading to diameter stenosis of $\geq 50 \%$ in vessels of $\geq 1.5 \mathrm{~mm}$ were scored separately and added together to provide the cumulative SYNTAX score, which was prospectively calculated using the SYNTAX score algorithm on the baseline diagnostic angiogram [7]. Two experienced interventional cardiologists, who were blinded to the clinical characteristics and laboratory results of the patients, examined coronary angiograms, collateral grading, and SYNTAX score. The opinion of a third analyst was obtained, and the final judgment was made by consensus in cases of disagreement.

The preprocedural flow status of the IRA was graded according to the Thrombolysis in Myocardial Infarction (TIMI) grading system [8]. TIMI grade 0-1 flow was considered as total occlusion (TO), TIMI 2 flow as partial recanalization (PR), and TIMI 3 flow as complete recanalization (CR) of the IRA. The same flow evaluation of the IRA was carried out at the end of the procedure. Thrombus burden classification was graded $(G)$ as $G 0=n o$ thrombus, G1=possible thrombus, G2=small [greatest dimension $\leq 1 / 2$ vessel diameter (VD)], G3=moderate $(>1 / 2$ but $<2$ VD), G4=large ( $\geq$ 2VD), G5=unable to assess TB due to vessel occlusion.

The characteristics of individual coronary lesions of each patient, predilatation of major and lateral lesions before and after thrombosis scoring, predilatation of the main branch and/or side diameter, stent diameter, length, stent type, main branch proximal, diameters before and after side branch stent, complications during the intervention, TIMI flow grades before and after stenting were recorded. Side branch loss was found to be <TIMI 3 in side branch after main branch stenting. The side branch damage was considered to be over $70 \%$ of the lesion percentage after the procedure when the lesion grade was below $70 \%$. Criteria for side branch intervention were: TIMI $<3$ flow in the side branch after main branch stenting, $70 \%$ lesion in side branch, or dissection.

All bifurcation lesions were classified according to the Medina classification, in which the proximal main vessel, distal main vessel, and side branch components of the bifurcation are respectively allocated a score of 1 or 0 depending on the presence or absence of $>50 \%$ diameter stenosis [9]. Medina classification was based on the operator's visual inspection. True bifurcation lesions were defined as lesions significantly involved in both the main vessel and the ostium of the side branch.

In the provisional group, the main vessel was stented with provisional technique. Prestent predilatation was left at the discretion of the operator. In the two-stent group, both main vessel and side branch stent technique were applied. According to the discretion of the operator, the patient has treated with Culotte, mini-Crush and $\mathrm{V}$ stenting.

Technical success was defined as successful revascularization with achievement of $\leq 30 \%$ diameter stenosis within the treated segment and restoration of TIMI grade 3 flow in at least one lesion treated during the procedure. Procedural success was defined as technical success without any major procedural complications.

\section{Statistical analysis}

All analyzes were performed using SPSS 20.0 (Chicago, IL, USA) statistical software package. Continuous variables in group data were expressed as mean \pm standard deviation (mean \pm SD). Categorical variables were given by number and percentage. The "chi-square" test was used to compare the categorical variables. Comparisons of continuous variables were made with the Student-T test. Statistical significance was accepted as $p<0.005$. 


\section{Results}

\section{Demographic and laboratory data}

Of the 2992 consecutive patients presenting with $\mathrm{MI}$ and underwent $\mathrm{PCl}$ for infarct-related artery, a total of 385 patients who had bifurcation lesions were included. A comparison of clinical and laboratory characteristics between the groups are shown in Table 1.

Overall, most patients were men (73.5\%), with mean age of $59.7 \pm 12.7$ years. More than $1 / 3(40 \%)$ of the patients had a history of hyperlipidemia, 44\% (168) patients diagnosed as STEMI whereas $56 \%$ (217) diagnosed as non-STEMI. $119(70.4 \%)$ of patients with STEMI diagnosis were found to have anterior $\mathrm{MI}, 34$ $(20.1 \%)$ had posterior $\mathrm{MI}$, and $16(9.5 \%)$ had inferior Ml (Table 1-3).

The mean procedure time was $15.2 \pm 14.1$ minutes in provisional stenting group, and $40.2 \pm 24.9$ minutes in two-stent group $(p<0.001)$. Side branch loss was observed in $40(11.3 \%)$ patients in provisional stenting group, and 1 $(3.3 \%)$ patient in two-stent group $(p=0.2)$. Onemonth mortality was $4.2 \%$ in the provisional stenting group, whereas $3.3 \%$ in two stent group $(p=0.8)$. The mortality at the end of the first year was similar between the groups $(11.5 \%$ in provisional stenting vs. $13.3 \%$ in two-stent technique; $p=0.7$ ). Procedure time, side branch loss and mortality data are shown in Table 2 .

\section{Culprit lesion features}

The mean SYNTAX score was 14.7 \pm 6.7 . The culprit lesion was LAD artery in 245 patients, whereas $\mathrm{Cx}$ artery in 98 patients, RCA in 36 patients and LMCA in 6 patients. The angiographic characteristics of the study population are demonstrated in Table 3.

\section{Procedural features}

In 275 patients, both main vessel and side branches were wired. On the other hand, in 110 patients only main vessels were wired. $173(44.9 \%)$ patients underwent main vessel predilatation. $61(15.8 \%)$ patients underwent side branch predilation. 355 (92.2\%) patients were treated with provisional technique and $30(7.8 \%)$ patients were treated with two-stent technique. 163 (45.9\%) patients in the provisional stent group had the diagnosis of STEMI. The classical provisional method was applied to 340
$(88.3 \%)$ of the patients in the provisional group, meanwhile 15 patients (3.9\%) were treated with inverted provisional technique. In the two-stent group, 24 patients were treated with mini-Crush technique, 3 patients with Culotte technique, and 3 patients with $\mathrm{V}$-stenting.

In the two-stent group, final kissing was done in all of the patients who were treated with Culotte technique. Final kissing was not performed in 2 of the patients who were treated with mini-Crush technique.

Among 355 provisional stenting patients, $315(88.7 \%)$ had TIMI 3 flow grade after revascularization. TIMI flow grade of main vessels and side branches after revascularization is shown in Table 4.

\section{Discussion}

In this single-center study, we demonstrated that procedural success, side branch loss, as well as short and long term mortality were similar with both provisional and two-stent techniques in patients presenting with ACS and bifurcation lesions.

Although many studies have compared the provisional and two-stent techniques for treating bifurcation lesions, few have focused on bifurcation stenting techniques in patients with and without ACS. In a previous study, the impact of bifurcation $\mathrm{PCl}$ in patients with non-STEMI and those with stable angina pectoris was investigated [10]. The authors claimed that $\mathrm{PCl}$ for bifurcation lesions in patients with non-STEMI is associated with worse clinical outcomes than in patients with stable angina pectoris. In a recent study, Kim et al. demonstrated that planned one-stenting reduced target vessel failure in patients with acute coronary syndromes when compared to patients with stable angina for the treatment of coronary bifurcation lesions [11].

The BBC ONE (The British Bifurcation Coronary Study: Old, New, and Evolving Strategies) study randomized 500 subjects to bifurcation stenting using either a simple (provisional T) or complex (Crush or Culotte) approach [12]. Consistent with our study, there were no significant differences in death events in the 9-month follow-up of patients. 169 patients were treated with Crush and 75 patients were treated with Culotte technique. 
Table 1. Comparison of clinical and laboratory characteristics between the groups

\begin{tabular}{|c|c|c|c|c|}
\hline Variables & $\begin{array}{l}\text { All population } \\
(n: 385)\end{array}$ & $\begin{array}{l}\text { Provisional technique } \\
\text { (n:355) }\end{array}$ & $\begin{array}{l}\text { Two- stent technique } \\
(\mathrm{n}: 30)\end{array}$ & $p$ value \\
\hline Age & $59.69 \pm 12.66$ & $59.41 \pm 12.40$ & $63.06 \pm 15.17$ & 0.129 \\
\hline Gender (male) n (\%) & 283 & 266 & 17 & 0.030 \\
\hline Hypertension & 196 & 180 & 16 & 0.782 \\
\hline Diabetes mellitus & 81 & 74 & 7 & 0.748 \\
\hline Smoking & 106 & 97 & 9 & 0.753 \\
\hline Coronary artery disease & 39 & 35 & 4 & 0.527 \\
\hline Hyperlipidemia & 379 & 351 & 28 & 0.085 \\
\hline \multicolumn{5}{|l|}{ Laboratory findings } \\
\hline Hemoglobin (g/dl) & $14.1 \pm 9.9$ & $14.09 \pm 7.85$ & $13.35 \pm 2.19$ & 0.613 \\
\hline Hemotocrit (\%) & $38.9 \pm 5.6$ & $39.72 \pm 5.29$ & $39.26 \pm 5.84$ & 0.656 \\
\hline Platelet (10^3/uL) & $228.6 \pm 73.1$ & $232.05 \pm 65.46$ & $241.41 \pm 87.69$ & 0.473 \\
\hline Urea (mg/dl) & $36.5 \pm 19.0$ & $35.71 \pm 24.12$ & $31.65 \pm 10.73$ & 0.370 \\
\hline Uric acid (mg/dl) & $5.7 \pm 1.6$ & $5.68 \pm 1.57$ & $5.25 \pm 1.21$ & 0.149 \\
\hline Creatinine (mg/dl) & $1.0 \pm 0.8$ & $0.98 \pm 0.73$ & $0.85 \pm 0.20$ & 0.316 \\
\hline $\begin{array}{l}\text { Total cholestrol } \\
\text { (ng/dl) }\end{array}$ & $188.3 \pm 47.0$ & $188.69 \pm 47.98$ & $183.06 \pm 32.99$ & 0.536 \\
\hline LDL (ng/dl) & $128.0 \pm 43.6$ & $128.33 \pm 44.73$ & $123.89 \pm 25.68$ & 0.598 \\
\hline HDL (ng/dl) & $38.3 \pm 10.5$ & $38.17 \pm 10.57$ & $39.23 \pm 9.81$ & 0.604 \\
\hline Triglycerides (ng/dl) & $163.6 \pm 117.7$ & $163.94 \pm 119.71$ & $159.87 \pm 91.39$ & 0.858 \\
\hline CK-MB (ng/dl) & $75.4 \pm 95.1$ & $77.57 \pm 97.02$ & $48.72 \pm 62.79$ & 0.116 \\
\hline Troponin T (ng/dl) & $1608 \pm 2714.0$ & $1655.21 \pm 2764.06$ & $1047.70 \pm 1964.13$ & 0.247 \\
\hline
\end{tabular}

LDL: low density lipoprotein, HDL: high density lipoprotein

Table 2. Procedure time, side branch loss and mortality data

\begin{tabular}{llll}
\hline & $\begin{array}{l}\text { Provisional } \\
\text { technique }(\mathbf{n})\end{array}$ & $\begin{array}{l}\text { Two-stent } \\
\text { technique (n) }\end{array}$ & p value \\
\hline Procedure time, min & $15.2 \pm 14.1$ & $40.2 \pm 24.9$ & $<0.001$ \\
Angiography time, $\min$ & $28.3 \pm 17.7$ & $51.3 \pm 24.6$ & $<0.001$ \\
Side branch loss, $\mathbf{n}(\%)$ & $40(11.3)$ & $1(3.3)$ & 0.230 \\
Mortality (one month), $\mathbf{n}(\%)$ & $15(4.2)$ & $1(3.3)$ & 0.808 \\
Mortality (one year), $\mathbf{n}(\%)$ & $41(11.5)$ & $4(13.3)$ & 0.767 \\
\hline
\end{tabular}


Table 3. Angiographic characteristics of the study population

\begin{tabular}{|c|c|c|c|c|c|}
\hline & & $\begin{array}{l}\text { Total population } \\
\text { n (\%) }\end{array}$ & $\begin{array}{l}\text { Provisional } \\
\text { technique } \\
\text { n (\%) }\end{array}$ & $\begin{array}{l}\text { Two- stent } \\
\text { technique } \\
\text { n (\%) }\end{array}$ & $p$ value \\
\hline \multicolumn{6}{|l|}{ Presentation } \\
\hline & STEMI & $168(\%)$ & 163 & 5 & \\
\hline & Non-STEMI & $217(\%)$ & 192 & 25 & \\
\hline SYNTAX score & & 14.76 & 14.58 & 16.76 & 0.091 \\
\hline \multirow[t]{4}{*}{ Culprit lesion } & LAD & $245(\%)$ & 223 & 22 & \\
\hline & $\mathrm{CX}$ & $98(\%)$ & 92 & 6 & \\
\hline & $\mathrm{RCA}$ & $36(\%)$ & 36 & 0 & \\
\hline & LMCA & $6(\%)$ & 4 & 2 & \\
\hline \multicolumn{6}{|l|}{ Medina classification } \\
\hline & 0.1 .0 & $103(26.7 \%)$ & 103 & 0 & \\
\hline & 1.1 .1 & $97(25.1 \%)$ & 75 & 22 & \\
\hline & 1.1 .0 & $94(24.4 \%)$ & 94 & 0 & \\
\hline & 1.0 .0 & $35(9.0 \%)$ & 35 & 0 & \\
\hline & 0.0 .1 & $26(6.7 \%)$ & 25 & 1 & \\
\hline & 0.1 .1 & $22(5.7 \%)$ & 17 & 5 & \\
\hline & 1.0 .1 & $8(2.0 \%)$ & 6 & 2 & \\
\hline $\begin{array}{l}\text { Thrombus classification } \\
\text { grade }\end{array}$ & & 2.04 & 3.70 & 2.76 & 0.015 \\
\hline Tirofiban usage & & $109(28.3)$ & $107(30.1)$ & $2(6.7)$ & 0.005 \\
\hline $\begin{array}{l}\text { Percent of proximal } \\
\text { main vessel lesion (\%) }\end{array}$ & & $55.96 \pm 44.70$ & $54.92 \pm 45.27$ & $68.33 \pm 35.54$ & 0.115 \\
\hline $\begin{array}{l}\text { Percent of distal main } \\
\text { vessel lesion (\%) }\end{array}$ & & $77.49 \pm 33.92$ & $77.37 \pm 34.75$ & $78.75 \pm 23.54$ & 0.838 \\
\hline $\begin{array}{l}\text { Percent of side branch } \\
\text { lesion (\%) }\end{array}$ & & $39.04 \pm 40.48$ & $34.26 \pm 38.91$ & $90.57 \pm 8.91$ & $>0.001$ \\
\hline
\end{tabular}

Table 4. TIMI flow after revascularization

\begin{tabular}{lllll}
\hline & TIMI-0 (\%) & TIMI-1 (\%) & TIMI-2 (\%) & TIMI-3 (\%) \\
\hline Proximal main vessel & $0(0 \%)$ & $0(0 \%)$ & $1(0.3 \%)$ & $384(99.7 \%)$ \\
Distal main vessel & $2(0.5 \%)$ & $2(0.5 \%)$ & $6(1.6 \%)$ & $375(97.4 \%)$ \\
Side branch & $20(5.2 \%)$ & $7(1.8 \%)$ & $14(3.6 \%)$ & $344(89.4 \%)$ \\
\hline
\end{tabular}

Final kissing was applied to $122(72 \%)$ of the patients who underwent Crush and 67 (89\%) of the patients who underwent Culotte technique. We performed final kissing balloon inflation for all patients in the two-stent group except 2 patients who were treated with mini-Crush.

In the DKCRUSH-II study (Double Kissing Crush versus Provisional Stenting Technique for Treatment of Coronary Bifurcation Lesions) a total of 370 patients with coronary bifurcation lesions were randomly assigned to either double kissing Crush or provisional stenting group and followed for 5 years [13]. It was observed that double kissing Crush stenting technique for coronary bifurcation lesions is associated with a lower rate of target lesion revascularization, but there was no significant difference in 6-month mortality. Likewise, in our study we observed that the mortality rates are similar in 1 and 12 months between provisional stenting and twostent technique. Moreover, in our study we performed mini-Crush, Culotte and $\mathrm{V}$ stenting 
techniques, whereas only double kissing crush technique was used in DKCRUSH-II study.

In the NORDIC (Nordic Bifurcation Study) study, patients with a coronary bifurcation lesion were randomly assigned to a simple stenting strategy of the main vessel and optional stenting of the side branch or a complex stenting strategy [14]. At 5-year follow-up in the Nordic Bifurcation Study, the clinical outcomes after simple optional side branch stenting remained at least equal to the more complex strategy of planned stenting of both the main vessel and the side branch. The main difference in our study from the NORDIC study is that, we included STEMI patients and patients with LMCA lesions in our study. However similar outcomes were observed with basic stenting in both studies.

The CACTUS (Coronary Bifurcations: Application of the Crushing Technique Using Sirolimus-Eluting Stents) study is a multicenter randomized-prospective study comparing stenting of only the main branch, with provisional side-branch T-stenting with crush stenting in patients with true bifurcation lesions [15]. Contrary to our study, patients with LMCA lesions and STEMI were excluded. There was no significant difference between angiographic restenosis rates in both groups. This study failed to demonstrate that the Crush stenting technique was superior to reducing the restenosis rate compared to the provisional stenting technique.

All the abovementioned studies have some limitations. There is no data on the actual bifurcation rate in the NORDIC study. This is regarded as a limitation of this study. The limitations of the CACTUS study, however, are that patients have focal lesions in the side branch and that patients have only 6-months follow-up results. However, the NORDIC study had both 6-month and 5-year results.

European Bifurcation Club suggests provisional stenting as the first choice and suggests an elective double stent strategy in the presence of a large ostial lesion with side branch and a lateral branch lesion> $3 \mathrm{~mm}$ long [16]. The European Society of Cardiology (ESC), published in 2014, recommends provisional stenting as class Ila in myocardial revascularization guide bifurcation lesions.
DKCRUSH-V Randomized Trial; The authors randomized 482 patients from 26 centers in 5 countries with true distal left main bifurcation lesions to provisional stenting $(n=242)$ or DK crush stenting $(n=240)$. That patients have 13-months follow-up results. There was no significant difference in cardiac death between the groups [17]. 2018 ESC/EACTS Guidelines on myocardial revascularization suggest that stent implantation in the main vessel only, followed by provisional balloon angioplasty with or without stenting of the side branch, is recommended for $\mathrm{PCl}$ of bifurcation lesions [18].

The most important complication in the provisional stent is side branch loss and the incidence of side branch loss is $12-41 \%$ [19, 20]. In our study, we observed that side branch loss is $11.3 \%$ in the provisional stenting group. When we compared two groups in our study, the side branch loss was higher in the provisional group but no statistically significant difference was found.

We used a retrospective single registry; therefore, our results were affected by limitations inherent to this type of study.

Our study has several limitations. First, we used a retrospective single-center experience; therefore, our results were affected by limitations inherent to this type of study. Second, systemic angiographic follow-up was not performed, and coronary angiography was analyzed qualitatively, not quantitatively. Detailed quantitative analysis of the angiographic data would help interpret our findings. Also, selection of the provisional or two-stent strategy was also at the discretion of the operators; therefore, patients who had complex bifurcation lesion morphology more frequently received two stents. Third, we did not use additional tests such as IVUS and FFR in detecting coronary lesions, which may restrict to evaluate detailed lesion characteristics.

In summary, we demonstrated that procedural success, side branch loss, as well as short and long term mortality were similar with both provisional and two-stent techniques in patients presenting with ACS and bifurcation lesions.

Conflict of interest: No conflict of interest was declared by the authors. 


\section{References}

1. Falk E, Shah PK, Fuster V. Coronary plaque disruption. Circulation 1995;92:657-671. https://doi. org/10.1161/01.cir.92.3.657

2. Ross R. Atherosclerosis--an inflammatory disease. $\mathrm{N}$ Engl J Med 1999;340:115-126. https://doi.org/10.1056/ NEJM199901143400207

3. Fuster V, Badimon L, Badimon $\mathrm{J}$, et al. The pathogenesis of coronary artery disease and acute coronary syndromes. N Engl J Med 1992;326:242250. https://doi.org/10.1056/NEJM199201233260406

4. Takebayashi $\mathrm{H}$, Haruta $\mathrm{S}$, Kohno $\mathrm{H}$, et al. Immediate and 3-month follow-up outcome after cutting balloon angioplasty for bifurcation lesions. J Interv Cardiol 2004;17:1-7. https://doi.org/10.1111/j.15408183.2004.00246.x

5. Yamashita T, Nishida T, Adamian MG, et al. Bifurcation lesions: two stents versus one stent--immediate and follow-up results. J Am Coll Cardiol 2000;35:11451151. https://doi.org/10.1016/s0735-1097(00)00534-9

6. Thygesen K, Alpert JS, Jaffe AS, et al. Third universal definition of myocardial infarction. J Am Coll Cardiol 2012;60:1581-1598. https://doi.org/10.1016/j. jacc.2012.08.001

7. Sianos G, Morel MA, Kappetein AP, et al. The SYNTAX Score: an angiographic tool grading the complexity of coronary artery disease. Eurolntervention 2005;219227.

8. TIMI Study Group. The Thrombolysis in Myocardial Infarction (TIMI) trial. Phase I findings. TIMI Study Group. N Engl J Med 1985;312:932-936. https://doi. org/10.1056/NEJM198504043121437

9. Thomas $M$, Hildick-Smith $D$, Louvard $Y$, et al. Percutaneous coronary intervention for bifurcation disease: a consensus view from the first meeting of the European Bifurcation Club. Eurolntervention 2006;2:149-153

10. Sang Song P, Ryeol Ryu D, Choi SH, et al. Impact of acute coronary syndrome classification and procedural technique on clinical outcomes in patients with coronary bifurcation lesions treated with drug-eluting stents. Clin Cardiol 2012;35:610-618. https://doi.org/10.1002/ clc. 22020

11. Kim MC, Ahn Y, Sun Sim D, et al. Comparison of the planned one- and elective two-stent techniques in patients with coronary bifurcation lesions with or without acute coronary syndrome from the COBIS II Registry. Catheter Cardiovasc Interv 2018;92:10501060. https://doi.org/10.1002/ccd.27551

12. Hildick Smith $\mathrm{D}$, de Belder $\mathrm{AJ}$, Cooter $\mathrm{N}$, et al. Randomized trial of simple versus complex drugeluting stenting for bifurcation lesions: the British Bifurcation Coronary Study: old, new, and evolving strategies. Circulation 2010;121:1235-1243. https:// doi.org/10.1161/CIRCULATIONAHA.109.888297
13. Chen SL, Santoso T, Zhang JJ, et al. A randomized clinical study comparing double kissing crush with provisional stenting for treatment of coronary bifurcation lesions: results from the DKCRUSH-II (Double Kissing Crush versus Provisional Stenting Technique for Treatment of Coronary Bifurcation Lesions) trial. J Am Coll Cardiol 2011;57:914-920. https://doi. org/10.1016/j.jacc.2010.10.023

14. Maeng M, Holm NR, Erglis A, et al. Long-term results after simple versus complex stenting of coronary artery bifurcation lesions: Nordic Bifurcation Study 5-year follow-up results. J Am Coll Cardiol 2013;62:30-34. https://doi.org/10.1016/j.jacc.2013.04.015

15. Colombo A, Bramucci E, Sacca S, et al. Randomized study of the crush technique versus provisional side-branch stenting in true coronary bifurcations: The CACTUS (Coronary bifurcations: Application of the Crushing Technique Using Sirolimus-eluting stents) study. Circulation 2009;119:71-78. https://doi. org/10.1161/CIRCULATIONAHA.108.808402

16. Lassen JF, Holm NR, Banning AP, et al. Percutaneous coronary intervention for coronary bifurcation disease: consensus from thefirst 10 years of the European Bifurcation Club meetings. Euro Interventiol 2014;10:545-560. https://doi.org/10.4244/EIJV10I5A97

17. Chen SL, Zhang JJ, Han Y, et al. Double kissing crush versus provisional stenting for left main distal bifurcation lesions: DKCRUSH-V randomized trial. J Am Coll Cardiol 2017;70:2605-2617. https://doi. org/10.1016/j.jacc.2017.09.1066

18. Neumann FJ, Sousa Uva M, Ahisson A, et al. 2018 ESC/ EACTS Guidelines on myocardial revascularization. Eur Heart J 2019;40:87-165. https://doi.org/10.1093/ eurheartj/ehy394

19. Cervinka P, Foley DP, Sabate M, et al. Coronary bifurcation stenting using dedicated bifurcation stents. Catheter Cardiovasc Interv2000;49:105-111. https://doi. org/10.1002/(sici)1522-726x(200001)49:1<105::aid$\operatorname{ccd} 25>3.0 . \mathrm{co} ; 2-2$

20. Timurkaynak T, Ciftci H, Ozdemir M, et al. Side branch occlusion after coronary stenting with or without balloon predilation: direct versus conventional stenting. J Invasive Cardiol 2002;14:497-501.

Ethics committee approval: The study was initiated after receiving approval from the Clinical Researches Ethical Committee (CREC) of the Adana Numune Training and Research Hospital (protocol number / date; 202 / 02.10.2015) 


\section{Contributions of authors}

H.H., M.G.: hypothesis

H.H., C.T., A.Q., G.A.: data collecting

T.Ş., A.O.B., O.G.: statistics

G.A., S.A.: text evaluation

H.H., A.O.B.: discussion 